Western North American Naturalist 67(4), (C) 2007, pp. 593-600

\title{
HOME RANGE SIZE OF BLACK-BACKED WOODPECKERS IN BURNED FORESTS OF SOUTHWESTERN IDAHO
}

\author{
Jonathan G. Dudley ${ }^{1}$ and Victoria A. Saab ${ }^{2}$
}

\begin{abstract}
We examined home range size of Black-backed Woodpeckers (Picoides arcticus) in burned ponderosa pine (Pinus ponderosa) / Douglas-fir (Pseudotsuga menziesii) forests of southwestern Idaho during 2000 and 2002 (6 and 8 years following fire). Home range size for 4 adult males during the post-fledging period was 115.6-420.9 ha using the 95\% fixed-kernel method, and 150.4-766.1 ha using the 100\% minimum convex polygon method. Smoothed bootstrap estimates (95\%) were 130.0-521.9 ha. Home range sizes were significantly smaller 6 years after fire than 8 years after fire. Each male had from 2 to 8 areas of concentrated use within his home range. We provide recommendations for estimating area requirements of Black-backed Woodpeckers in post-fire ponderosa pine / Douglas-fir forests.
\end{abstract}

Key words: home range, Black-backed Woodpecker, Picoides arcticus, wildfire, coniferous forest, ponderosa pine, Douglas-fir, fixed-kernel method, minimum convex polygon method.

The Black-backed Woodpecker (Picoides arcticus) is a resident of coniferous forests of North America (Dixon and Saab 2000). It is uncommon and relatively inconspicuous across most of its range (Bock and Bock 1974). In the Pacific Northwest, the Black-backed Woodpecker is designated as a sensitive species by most state and federal agencies (Oregon Natural Heritage Information Center 2004, Rich et al. 2004, Washington State Department of Natural Resources 2004, Idaho Department of Fish and Game 2005, USDA Forest Service 2005).

Though Black-backed Woodpeckers have no regular latitudinal migration (Dixon and Saab 2000), several studies have documented local irruptions following forest fires (Blackford 1955, Villard and Schieck 1996), insect outbreaks (West and Speirs 1959, Lester et al. 1980), Dutch elm disease blights (Yunick 1985), and windthrow (Wickman 1965). During irruptions, numbers may increase several-fold, whereas prior to disturbance, few or none were present (e.g., Yunick 1985). Irruptions are usually temporary, and populations decline as food items decrease (Harris 1982, Murphy and Lehnhausen 1998).

Because of their narrow diet, consisting mainly of bark beetles and wood-boring beetles (Buprestidae, Cerambycidae, and Scolytidae; Beal 1911, Murphy and Lehnhausen 1998, Powell 2000), Black-backed Woodpeckers are closely associated with disturbed habitats where beetle populations may readily colonize (e.g., especially early post-fire habitats; Hutto 1995). However, Black-backed Woodpeckers may be vulnerable to local extinction if, for example, post-fire salvage logging reduces or eliminates high-quality habitats (Murphy and Lehnhausen 1998, Saab et al. 2007). This impact was observed in recently burned ponderosa pine (Pinus ponderosa) / Douglas-fir (Pseudotsuga menziesii) forests of southwestern Idaho, where nesting densities of Black-backed Woodpeckers were nearly 6 times lower in logged versus unlogged units (Saab et al. 2007). Similar results were reported in burned lodgepole pine (Pinus contorta) and Douglasfir-dominated forests of Montana (Caton 1996, Hutto and Gallo 2006) and in black spruce (Picea mariana) forests of eastern Canada (Schwab et al. 2006). Therefore, estimating the amount of area required by Black-backed Woodpeckers is critical when forest management activities include removal of required habitats, especially following fire where large landscapes are potentially affected. However, only 1 study has estimated home range size of Black-backed Woodpeckers in beetlekilled lodgepole pine forests of Oregon (Goggans et al. 1989), and no estimates of home range size have been reported after fire. Home range sizes have been inferred from anecdotal observations (61 ha, Lisi 1988; 40 ha, Hoyt 2000 ) and nesting densities (4 pairs in 500 ha,

${ }^{1}$ USDA Forest Service, Rocky Mountain Research Station, 322 East Front St., Suite 401, Boise, ID 83702. E-mail: jdudley@fs.fed.us

${ }^{2}$ USDA Forest Service, Rocky Mountain Research Station, 1648 South 7th Ave., Bozeman, MT 59717. 


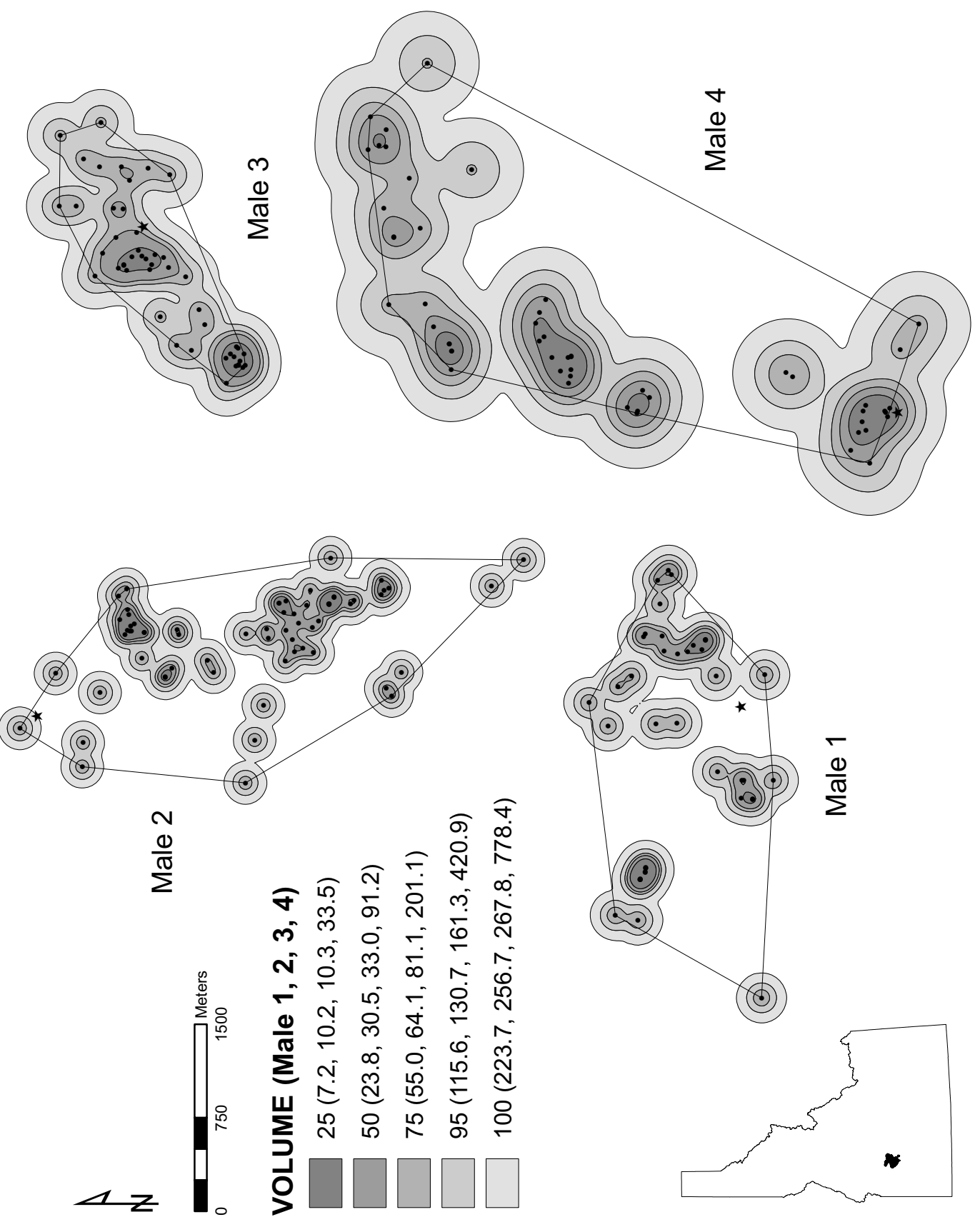

Fig. 1. Black-backed Woodpecker study area and home ranges in southwestern Idaho in 2000 and 2002. Home ranges for 4 adult males were derived using the minimum convex polygon method (solid line) and fixed-kernel method (shaded polygons). The shaded polygons represent predicted use (i.e., utilization distribution volumes). Area (ha) for each volume is reported for males 1-4 in parentheses. Points represent radio-locations of foraging birds, and stars denote nest locations. Spatial arrangement of home ranges is for illustration only. 
TABLE 1. Home range size (ha) for radio-tagged Black-backed Woodpeckers in ponderosa pine / Douglas-fir forests of southwestern Idaho, 6 and 8 years following fire.

\begin{tabular}{|c|c|c|c|c|c|c|}
\hline \multirow[b]{2}{*}{ Time since fire ${ }^{\mathrm{a}}$} & \multirow[b]{2}{*}{$n$} & \multirow[b]{2}{*}{ Distance $^{\mathrm{b}}(\mathrm{m})$} & \multicolumn{2}{|c|}{$\mathrm{MCPc}$} & \multirow[b]{2}{*}{$95 \% \mathrm{FK}^{\mathrm{d}}$} & \multirow[b]{2}{*}{$95 \%$ bootstrape } \\
\hline & & & $95 \%$ & $100 \%$ & & \\
\hline \multicolumn{7}{|l|}{6 years } \\
\hline Male 1 & 42 & $673.8(91.6)$ & 233.6 & 354.6 & 115.6 & $130.0(118.2-141.8)$ \\
\hline Male 2 & 66 & $646.1(65.8)$ & 359.0 & 445.9 & 130.7 & $139.2(131.1-147.4)$ \\
\hline \multicolumn{7}{|l|}{8 years } \\
\hline Male 3 & 48 & $644.8(84.4)$ & 123.5 & 150.4 & 161.3 & $174.7(158.4-191.0)$ \\
\hline Male 4 & 53 & $860.8(115.5)$ & 573.4 & 766.1 & 420.9 & $521.9(470.9-572.9)^{a}$ \\
\hline
\end{tabular}

aMales 1-3 were radio-tracked in 2000, male 4 in 2002

bMean distance between successive radiotelemetry relocations. Standard errors are in parentheses.

cMinimum convex polygon method.

dFixed-kernel method.

eSmoothed bootstrap mean area (95\% confidence interval).

Dixon and Saab 2000; 9 pairs in 200 ha, Powell 2000; 15 nests in 100 ha, Nappi et al. 2003). We caution, however, against using these estimates, because they do not include documented movements of individuals, including foraging locations. Our objectives were to estimate and compare between-year home range sizes of Black-backed Woodpeckers in burned ponderosa pine / Douglas-fir forests of southwestern Idaho.

The study area was located in the 1992 Foothills and 1994 Star Gulch burns on the Boise National Forest in southwestern Idaho (Ada, Boise, and Elmore Counties; Fig. 1). The Foothills Burn was created in 1992 by a mixedseverity fire, and about $40 \%$ of snags over $23 \mathrm{~cm}$ diameter at breast height (dbh) were harvested after the fire (Saab et al. 2007). The 1994 Star Gulch Fire was also of mixed severity, and the burned area was principally unlogged following the wildfire; 2 survey units (each $1000 \mathrm{ha}$ ) in the Star Gulch Burn were excluded from logging. Study site elevation ranged from 1100 to $2100 \mathrm{~m}$ and the perimeters of the burns were separated by $0.6 \mathrm{~km}$, on average. Prefire vegetation in both wildfire sites was similar and dominated by ponderosa pine and Douglas-fir, with quaking aspen (Populus tremuloides), subalpine fir (Abies lasiocarpa), and buckbrush (Ceanothus spp.; Saab et al. 2004). Prelogging snag densities, prefire crown closure, and burn severity of the 2 study sites were similar (Saab et al. 2007). Tree and snag densities in home ranges averaged 296 snags $\cdot \mathrm{ha}^{-1}$ for conifers $\geq 1.37 \mathrm{~m}$ in height (range 107-455 snags $\cdot \mathrm{ha}^{-1}$; Dudley 2005).

During April-May 2000 and 2002, we searched burned forests where Black-backed
Woodpeckers were previously found nesting (Saab et al. 2004). Adults were located by frequently broadcasting a tape recording of Blackbacked Woodpecker drumming and calling. We investigated responses and followed birds to their nests. We located 9 nests ( 1 in the Foothills Burn, 8 in the Star Gulch Burn) in 2000, and 3 nests (all in the Star Gulch Burn) in 2002. We surveyed approximately 2400 ha each year. After a nest was located, we viewed the cavity contents with a pole-mounted pinhole camera (Wilco Precision, Inc., Morris, MN) to determine the nest's status.

Black-backed Woodpeckers are known to abandon eggs and recently hatched young after trapping and handling (Nancy J. Hoffman, U.S. Fish and Wildlife Service, personal communication). Therefore, to reduce the risk of nest abandonment, we waited until nestlings were 3-4 days old before attempting to capture adults. In addition, we concentrated trapping during the period when adults completely entered the cavity to feed nestlings (up to 10 days after hatching). We placed a modified "butterfly net" over the entrance, which entangled the adult when it exited (Goggans et al. 1989).

To further reduce the likelihood of nest failure, we randomly selected only 1 adult for radio-tagging. In 2000, we captured and tagged males 1 and 2 (Star Gulch Burn), and male 3 (Foothills Burn), and in 2002 we tagged male 4 (Table 1). All nests of radio-tagged males fledged at least 2 young. We used cyanoacrylate glue and braided fishing line to secure a 2.0 g radiotransmitter (model BD-2G, $150 \mathrm{MHz}, 12-16$ week battery life, Holohil Systems Limited, Carp, Ontario, Canada) to the dorsal side of a central rectrix following capture (Goggans et al. 
1989). These radios are commonly used for similarly sized Picoides woodpeckers (e.g., Pechacek 2004, Covert-Bratland et al. 2006), and represent the required $2 \%-3 \%$ of the total body weight (range 69-77 g) of our males (Gustafson et al. 1997). We observed no negative effects due to the radio attachments. We relocated birds using an Advanced Telemetry Systems, Inc., (Isanti, MN) receiver and $\mathrm{H}$-antenna (148-152 MHz).

Radio-tracking began the 1st day after nestlings fledged and adult males attended at least 1 fledgling. We chose the post-fledging period in order to reduce human disturbance during nesting and to ensure an adequate sample size (at least 40-50 locations for each male) over a discrete period. We located each male daily, during 1 of 5 randomly assigned 3-hour time blocks (06:00-08:59, 09:00-11:59, 12:00-14:59, $15: 00-17: 59,18: 00-20: 59)$. If 2 or more males were assigned to the same 3-hour block and were logistically prohibitive to locate within the period, then 1 or more males were reassigned to another block.

Upon observing a radio-tagged male, we collected global positioning system (GPS) data to represent the location of the 1st tree or snag where he was observed foraging. Coordinate pairs for all GPS data were calculated by averaging a minimum of 180 satellite-derived positions, and all locations were differentially corrected for rover inaccuracy using GPS Pathfinder Office software (Trimble Navigation Limited 2001). If a male was not visually located during a 3-hour time block, we continued searching until he was found. Data from these locations were individually assessed to determine if they should be included in further analyses. We radio-tracked males for 9-12 weeks of the post-fledging period and analyzed only those telemetry relocations obtained while males attended their fledglings. Radios dropped off with the rectrix during the fall molt (Pyle and Howell 1995).

We calculated home ranges (Burt 1943) for each male using fixed-kernel (Worton 1989) and minimum convex polygon (MCP; Mohr 1947) methods. The fixed-kernel method was used because it is sensitive to multiple areas of concentrated use (i.e., nonparametric) and produces less area bias and better surface fit than adaptive-kernel estimates when sample sizes are small (Seaman and Powell 1996, Seaman et al. 1999). We used least-squares cross-vali- dation to estimate kernel bandwidth values (i.e., amount of smoothing) and then standardized the data to have equal variances for both $\mathrm{x}$ - and $y$-coordinates (i.e., variances $=1$ and covariances $=0$; Gitzen and Millspaugh 2003). No post hoc adjustments were performed.

To measure variance in home range estimates, we calculated surface fit error and area bias in each bird's home range from 1000 smoothed bootstrap samples. The smoothed bootstrap approach constructs home range estimates from a simulated distribution function rather than from the empirical distribution function (the unsmoothed bootstrap approach; Silverman 1986). Samples do not contain repeat values and simulated estimates have less bias with small sample sizes (Silverman 1986, Kernohan et al. 2001). We used The Home Ranger software for all fixed-kernel procedures (Hovey 2000).

The minimum convex polygon method was used to permit comparisons of results among other studies (Harris et al. 1990); however, caution is warranted when comparing estimates because MCP is sensitive to sample size and "outlier" locations, and insensitive to areas of concentrated use (White and Garrot 1990, Seaman et al. 1999). We used CALHOME software for all minimum convex polygon procedures, and no tests were performed to detect outliers (Kie et al. 1996).

We calculated area-observation curves to determine the number of telemetry locations (sample size) necessary for accurate home range estimates (Harris et al. 1990). Sample sizes were considered adequate when additional observations yielded little or no increase in home range size (i.e., when the area-observation curves reached an asymptote; Odum and Kuenzler 1955).

We collected 225 radio-telemetry relocations from 3 males during 8 June-10 September 2000 , and 82 relocations from 1 male during 24 June-13 September 2002 (Table 1). Not all relocations were unique. On 35 occasions, males were observed at previously visited locations. Although most locations were only revisited once, 2 birds revisited 1 telemetry location 4 times. Revisits usually occurred within 1-3 days of the initial visit, but the bird may have continued to return intermittently for up to 3 weeks. Mean distances between successive relocations ranged from 644.8 to 860.8 m (Table 1). Individual movements between 
visits ranged from 0 to $4.52 \mathrm{~km}$, and each male had 2 or more areas of concentrated use (Fig. 1).

Area-observation curves during the postfledging period reached an asymptote for 3 males after 41 consecutive relocations (range 30-48). Curves for male 3 reached an asymptote after 57 relocations, 9 days after separation from his fledgling.

Home range sizes ranged from 150.4 to 766.1 ha for the $100 \%$ MCP, and from 115.6 to 420.9 ha for the $95 \%$ fixed-kernel estimate (Table 1). One telemetry relocation was included in home range analyses even though it was collected outside of its assigned time block because the location represented use of habitats that otherwise would have been undetected (male 3). Inclusion of this movement increased the $95 \%$ fixed-kernel home range estimate nearly $7 \%$. According to $95 \%$ smoothed bootstrap mean areas, $95 \%$ fixed-kernel home ranges were underestimated by 6\%-19\%. Smoothed bootstrap mean areas ranged from 130.0 to 521.9 ha (Table 1).

Home range size varied among the 4 adult male Black-backed Woodpeckers during the post-fledging period. Estimates of home range size based on telemetry locations represent foraging habitat in addition to nesting habitat. Even though estimates of home range size can be inferred from nesting densities, such estimates do not represent foraging habitats, but they assume that animal movements do not overlap and that movements are restricted to a defined study area. Our home range estimates were up to 17 times larger than estimates inferred through nest densities in burned forests (Dixon and Saab 2000, Hoyt 2000, Powell 2000, Nappi et al. 2003). Such differences indicate that larger areas are required for foraging and that larger areas might be required during the postbreeding period, as was similarly reported for the closely related Eurasian Three-toed Woodpecker (Picoides tridactylus; Pechacek 2004). Home range estimates based solely on locations collected during the breeding season are likely inappropriate to determine the annual survival needs of Black-backed Woodpeckers. Furthermore, when one compares home range sizes among studies, we suggest that both the vegetation type and the time elapsed since disturbance should be considered.

Home range sizes estimated from the fixedkernel method were significantly larger at 8 years compared to 6 years post-fire, based on nonoverlapping confidence intervals for smoothed bootstrap home range sizes. This finding suggests that Black-backed Woodpeckers have larger home ranges in later years after fire to meet foraging requirements. Because beetle numbers decline with the time elapsed since fire (Murphy and Lehnhausen 1998, Powell 2000, Covert-Bratland et al. 2006), Black-backed Woodpeckers may have moved greater distances to find food (Kenward 2001). All males moved into adjacent unburned forest to varying degrees, suggesting that older burned forests (6-8 years post-fire) were less suitable as foraging habitat than recently burned forests (Covert-Bratland et al. 2006). One male had a home range 2-3 times larger than other males. He was often located at distances of $>1.4 \mathrm{~km}$ into adjacent unburned forest, where he foraged in patches with scattered dead and dying trees. Use of burn perimeters by foraging Black-backed Woodpeckers has also been reported in Alaska (Murphy and Lehnhausen 1998).

The movements of Black-backed Woodpeckers to the periphery of the burns suggest that beetle populations may have decreased within the interior of the burns (compare Rasmussen et al. 1996). Beetle dispersal into adjacent unburned forests could potentially provide critical foraging habitat at $4-5$ years post-fire, when Black-backed Woodpecker nesting densities decline in burned forests (Saab et al. 2007). During periods of infrequent forest fires, green forests adjacent to old burns may play a role in maintaining local populations of Blackbacked Woodpeckers until new forest burns are created. Additionally, unburned areas adjacent to the burns likely provide fledglings with increased hiding cover from avian predators. This might be particularly important when fledglings are $<15$ days old, a time when fledglings are relatively immobile and adults deliver their food. After the 15-day period, fledglings are more fully developed and better able to fly long distances, up to $2 \mathrm{~km}$ between successive relocations.

Area-observation curves reached asymptotes for only 3 males, suggesting a more accurate home range estimate for those 3 males compared to the 4th male. More importantly, however, locations of all males produced "stepped" curves throughout the sampling period, a function of having areas of concentrated use that 
potentially changed through time. This result points to the difficulty using area-observation curves for determining the sample sizes needed to estimate home range size of species that use patchily distributed habitats during transition periods (Harris et al. 1990, Gautestad and Mysterud 1995).

Fixed-kernel home range estimates varied less between birds than estimates calculated using the minimum convex polygon method. Previous home range estimates for Blackbacked Woodpeckers also varied greatly in beetle-killed forests, from 72 to 328 ha for 3 birds (100\% MCP, Goggans et al. 1989). Although our MCP home range estimates overlapped with these, we caution against comparing them directly because of important differences between the data collection protocols (Kernohan et al. 2001). In addition, our observations were primarily from burned ponderosa pine / Douglas-fir habitats 6 and 8 years following fire, whereas those of Goggans et al. (1989) were from beetle-killed lodgepole pine habitats during a 15-year epidemic. These differences alone could account for the variation in home range estimates derived from the 2 studies.

The home range sizes reported here are probably conservative because of limitations in our study design. Home range estimates did not include movements by females as they attended fledglings, although banded females were occasionally observed foraging in the same places, but at different times as their mates. Interactions between mates did occur (e.g., fledglings switching adults), but the degree of their home range overlap is unknown. In addition, the influence of untagged males (intraspecific interactions) on the movements of tagged males is unknown. Home range polygons did not overlap between tagged males, and interactions between tagged males only occurred after males no longer attended their fledglings. We observed occasional interspecific interactions at foraging sites between our radio-tagged Black-backed Woodpeckers and Hairy Woodpeckers (Picoides villosus). How these interactions may have affected home range sizes is inconclusive because the interactions (e.g., displacements from foraging locations) were localized on individual trees, occurred infrequently (i.e., were chance meetings), and were not consistently dominated by either species.

For estimating home range requirements of Black-backed Woodpeckers in dry coniferous forests, we suggest adopting an approach that considers the patchiness of foraging habitats (Wiktander et al. 2001). We recommend using home range estimates from both the MCP and fixed-kernel methods together. The fixed-kernel method is a better home range estimator when centers of activity exist (i.e., determining the relative amount of high-quality habitat, and here defined by areas with clumped telemetry locations compared to adjacent areas with no locations). In our study, we found 2-8 centers of activity of relatively high-quality habitats for each radio-tagged male. Highquality habitats in any landscape will most likely be patchily distributed (compare Russell et al. 2007).

Using fixed-kernel estimates alone could severely underestimate the extent of required habitat if high-quality habitats are isolated and vary greatly in size. Using MCP estimates will help incorporate these patchily distributed habitats when habitat quality is unknown. Used together, MCP and fixed-kernel home range estimates may delineate enough high-quality habitat area nested within an overall area to support Black-backed Woodpeckers during the post-fledging period. For example, in a 10,000-ha burn containing ponderosa pine / Douglas-fir forests, a potential of 23 Blackbacked Woodpecker home ranges is expected 6-8 years after fire if habitat quality is unknown (using the mean of $100 \%$ MCP estimates from all males, $\bar{x}=429.3 \mathrm{ha}, 10,000 / 429.3=23$ ). However, if habitat quality is uniformly poor, far fewer home ranges may actually exist. Similarly, if quality habitat is known and uniformly high, a potential of 48 home ranges is expected (using the mean of 95\% fixed-kernel estimates from all males, $\bar{x}=207.1 \mathrm{ha}$, $10,000 / 207.1=48$ ). More likely, however, high quality habitats will not be uniformly distributed within a burn. In this situation, we suggest that the extent of potential home ranges be estimated by adding the areas of all highquality habitats (patches) until approximately 200 ha $\left(207.1 \pm 71.9\right.$ ha, $\left.\bar{x} \pm \mathrm{s}_{\bar{x}}\right)$ are obtained. The extent of these areas (determined by encircling all the selected high-quality patches) should approximate 400 ha (429.3 \pm 128.1 ha). Caution should be exercised when applying these values to different forest types or to burns of different ages.

This research was supported primarily by the USDA Forest Service, Rocky Mountain 
Research Station and Boise National Forest, with additional funding provided by the $\mathrm{Na}$ tional Fire Plan, Joint Fire Science Program; the Idaho Department of Fish and Game; and the Golden Eagle Audubon Society. Two anonymous reviewers provided valuable comments on the manuscript. We thank L. Donohoo of the Boise National Forest for securing housing and logistical support. J. Schmidt, S. Cooper, and S. Carney were invaluable field assistants. B. Thompson offered significant guidance regarding study design. N. Hoffman provided helpful insights regarding capture of birds and attachment of radio-transmitters.

\section{Literature Cited}

BEAL, FE.L. 1911. Food of the woodpeckers of the United States. USDA Biological Survey Bulletin 37:25-27.

BLACKFORD, J.L. 1955. Woodpecker concentration in burned forest. Condor 57:28-30.

Bock, C.E., AND J.H. Bock. 1974. On the geographical ecology and evolution of the three-toed woodpeckers, Picoides tridactylus and P. arcticus. American Midland Naturalist 92:397-405.

BuRT, W.H. 1943. Territoriality and home range concepts as applied to mammals. Journal of Mammalogy 24: 346-352.

Caton, E.L. 1996. Effects of fire and salvage logging on the cavity-nesting bird community in northwestern Montana. Doctoral dissertation, University of Montana, Missoula.

Covert-Bratland, K.A., W.M. Block, and T.C. Theimer. 2006. Hairy Woodpecker winter ecology in ponderosa pine forests representing different ages since wildfire. Journal of Wildlife Management 70:1379-1392.

Dixon, R.D., AND V.A. SAAB. 2000. Black-backed Woodpecker (Picoides arcticus). In A. Poole and F. Gill, editors, Birds of North America No. 509. Birds of North America, Inc., Philadelphia, PA.

DudLEY, J.G. 2005. Home range size and foraging habitat of Black-backed Woodpeckers. Master's thesis, Boise State University, Boise, ID.

Gautestad, A.O., AND I. Mysterud. 1995. The home range ghost. Oikos 74:195-204.

Gitzen, R.A., and J.J. Millspaugh. 2003. Comparison of least-squares cross-validation bandwidth options for kernel home-range estimation. Wildlife Society Bulletin 31:823-832.

Goggans, R., R.D. Dixon, and L.C. Seminara. 1989. Habitat use by Three-toed and Black-backed Woodpeckers, Deschutes National Forest, Oregon. Nongame Wildlife Program Technical Report 87-3-02, Oregon Department of Fish and Wildlife, Portland.

Gustafson, M.E., J. Hildenbrand, and L. Metras. 1997. The North American bird banding manual [online]. Version 1.0. Auxiliary marking. Available from: http:// www.pwrc.usgs.gov/bbl/manual/aamarkus.htm

HARRIS, M.A. 1982. Habitat use among woodpeckers in forest burns. Master's thesis, University of Montana, Missoula.

Harris, S., W.J. Cresswell, P.G. Forde, W.J. Trewhella, T. Woolard, and S. Wray. 1990. Home-range analy- sis using radio-tracking data-a review of problems and techniques particularly applied to the study of mammals. Mammal Review 20:97-123.

Hovey, F.W. 2000. The Home Ranger. Version 1.6 beta. Ursus Software, Revelstoke, British Columbia, Canada.

HoYT, J.S. 2000. Habitat associations of Black-backed Picoides arcticus and Three-toed P. tridactylus Woodpeckers in the northeastern boreal forest of Alberta. Master's thesis, University of Alberta, Edmonton, Canada.

HutTo, R.L. 1995. Composition of bird communities following stand-replacement fires in northern Rocky Mountain (U.S.A.) conifer forests. Conservation Biology 9:1041-1058.

HutTo, R.L., AND S.M. Gallo. 2006. The effects of postfire salvage logging on cavity-nesting birds. Condor 108:817-831.

Idaho Department of Fish and Game. 2005. Idaho comprehensive wildlife conservation strategy. Appendix A, Common and scientific names for fish and wildlife species found in Idaho. Conservation Data Center, Idaho Department of Fish and Game, Boise. Available from: http://fishandgame.idaho.gov/cms/tech/CDC/ cwcs_pdf/appendix\%20a.pdf

KENWARD, R.E. 2001. A manual for wildlife radio tagging. Academic Press, San Diego, CA.

Kernohan, B.J., R.A. Gitzen, and J.J. Millspaugh. 2001. Analysis of animal space use and movements. Pages 125-166 in J.J. Millspaugh and J.M. Marzluff, editors, Radio tracking and animal populations. Academic Press, San Diego, CA.

Kie, J.G., J.A. Baldwin, and C.J. Evans. 1996. CALHOME: a program for estimating animal home ranges. Wildlife Society Bulletin 24:342-344.

Lester, A.N., B.R. McClelland, and J.H. Lowe, Jr. 1980. Numerical response of woodpeckers and their effects on mountain pine beetles in lodgepole pine in northwestern Montana. Proceedings of the 2nd Conference on Scientific Research in National Parks $12: 130-143$.

LisI, G. 1988. A field study of Black-backed Woodpeckers in Vermont. Vermont Fish and Wildlife Department Nongame and Endangered Species Program Technical Report 3. Vermont Fish and Wildlife Department, Waterbury.

Moнr, C. 1947. Table of equivalent populations of North American small mammals. American Midland Naturalist 37:223-249.

Murphy, E.C., And W.A. Lehnhausen. 1998. Density and foraging ecology of woodpeckers following a standreplacement fire. Journal of Wildlife Management 62: 1359-1372.

Nappi, A., P. Drapeau, J.-F. Giroux, and J.-P.L. Savard. 2003. Snag use by foraging Black-backed Woodpeckers (Picoides arcticus) in a recently burned eastern boreal forest. Auk 120:505-511.

Odum, E.P., And E.J. Kuenzler. 1955. Measurement of territory and home range size in birds. Auk 72:128137.

Oregon Natural Heritage Information Center. 2004. Rare, threatened and endangered species of Oregon. Oregon Natural Heritage Information Center, Oregon State University, Portland.

Pechacek, P. 2004. Spacing behavior of Eurasian Threetoed Woodpeckers (Picoides tridactylus) during the breeding season in Germany. Auk 121:58-67. 
Powell, H. 2000. The influence of prey density on postfire habitat use of the Black-backed Woodpecker. Master's thesis, University of Montana, Missoula.

Pyle, P., AND S.N.G. HowEll. 1995. Flight-feather molt patterns and age in North American woodpeckers. Journal of Field Ornithology 66:564-581.

Rasmussen, L.A., G.D. Amman, J.C. Vandygriff, R.D. Oakes, A.S. Munson, And K.E. Gibson. 1996. Bark beetle and wood borer infestation in the Greater Yellowstone area during four postfire years. Research Paper INT-RP-487. USDA Forest Service, Intermountain Research Station, Ogden, UT.

Rich, T.D., C.J. Beardmore, H. Berlanga, P.J. Blancher, M.S.W. Bradstreet, G.S. Butcher, D.W. Demarest, ET AL. 2004. Partners in flight North American landbird conservation plan. Cornell Lab of Ornithology, Ithaca, NY.

Russell, R.E., V.A. SAAB, And J.G. Dudley. 2007. Habitat-suitability models for cavity-nesting birds in a postfire landscape. Journal of Wildlife Management 71:2600-2611.

SAab, V.A., J. Dudley, AND W.L. Thompson. 2004. Factors influencing occupancy of nest cavities in recently burned forests. Condor 106:20-36.

SaAB, V.A., R.E. Russell, and J.G. Dudley. 2007. Nest densities of cavity-nesting birds in relation to postfire salvage logging and time since wildfire. Condor 109:97-108.

Schwab, F.E., N.P. Simon, S.W. Stryde, and G.J. Forbes. 2006. Effects of postfire snag removal on breeding birds of western Labrador. Journal of Wildlife Management 70:1464-1469.

Seaman, D.E., J.J. Millspaugh, B.J. Kernohan, G.C. Brundige, K.J. Raedeke, and R.A. Gitzen. 1999. Effects of sample size on kernel home range estimates. Journal of Wildlife Management 63:739-747.

Seaman D.E., And R.A. Powell. 1996. An evaluation of the accuracy of kernel density estimators for home range analysis. Ecology 77:2075-2085.

Silverman, B.W. 1986. Density estimation for statistics and data analysis. Chapman and Hall Ltd., London.

Trimble NAVIGATION Limited. 2001. GPS pathfinder office software. Version 2.80. Trimble Navigation Limited, Sunnyvale, CA.
USDA Forest Service. 2005. Forest Service designated sensitive species on the national forests and grasslands. Threatened, endangered, and sensitive species-TES. USDA Forest Service, Watershed, Fish, Wildlife, Air and Rare Plants, Washington, DC. Available from: http:/www.fs.fed.us/biology/resources/ pubs/tes/fs_ss_310ct05.pdf

VILLARD, M., AND J. SCHIECK. 1996. Immediate post-fire nesting by Black-backed Woodpeckers, Picoides arcticus, in northern Alberta. Canadian Field-Naturalist 111:478-479.

Washington State Department of Natural Resources. 2004. Washington Natural Heritage Information System, a partial list of animals in Washington. Washington Natural Heritage Program, Washington State Department of Natural Resources, Olympia. Available from: http:/www.dnr.wa.gov/nhp/refdesk/lists/ animal_ranks.html

West, J.D., AND J.M. SpeIRs. 1959. The 1956-1957 invasion of Three-toed Woodpeckers. Wilson Bulletin 71: 348-363.

White, G.C., And R.A. Garrot. 1990. Analysis of wildlife radio-tracking data. Academic Press, San Diego, CA.

Wickman, B.E. 1965. Black-backed Three-toed Woodpecker, Picoides arcticus, predation on Monochamus oregonensis (Coleoptera: Cerambycidae). Pan-Pacific Entomologist 41:162-164.

Wiktander, U., O. Olsson, And S.G. Nilsson. 2001. Seasonal variation in home-range size, and habitat area requirement of the Lesser Spotted Woodpecker (Dendrocopos minor) in southern Sweden. Biological Conservation 100:387-395.

Worton, B.J. 1989. Kernel methods for estimating the utilization distribution in home-range studies. Ecology 70:164-168.

YUNICK, R.P. 1985. A review of recent irruptions of the Black-backed Woodpecker and Three-toed Woodpecker in eastern North America. Journal of Field Ornithology 56:138-152.

Received 8 June 2006 Accepted 24 January 2007 